\title{
Introduction: The Culture of Jesuit Erudition in an Age of Enlightenment
}

\author{
Jeffrey D. Burson \\ Georgia Southern University \\ jburson@georgiasouthern.edu
}

\begin{abstract}
Although works on religious, specifically Catholic, and more specifically Jansenist, contributions to the Enlightenment abound, the contributions of the Jesuits to the Enlightenment have remained relatively unexplored since Robert R. Palmer initially identified affinities between Jesuit thought and the emergence of the French Enlightenment as long ago as 1939. Accordingly, this introduction and the essays contained within the pages of this special issue revisit and further explore ways in which the individual Jesuits contributed to broader patterns of European intellectual and cultural history during the age of Enlightenment. Taken together, the contributions to this special issue investigate different aspects of an important question: to what extent were some Jesuits (at time, despite themselves, and at times, even against the grain of the order's official positions) unlikely contributors to the Enlightenment? This question of whether one might speak of a specifically Jesuit Enlightenment is complicated by the still unsatisfactory scholarly consensus regarding the definition of the Enlightenment. But, growing scholarly attention to the nature of Catholic Enlightenment, and to the continuities linking eighteenth-century preoccupations to the controversies of the seventeenth century have further underscored the need for greater attention to Jesuit contributions to the Enlightenment itself. In this introduction, rather than considering the Enlightenment as a series of transformative and largely eighteenth-century debates rooted in the middle or late seventeenth century, I suggest that Jesuit engagement with the Enlightenment is best understood if the Enlightenment is more firmly anchored somewhat earlier in the culture of late Humanism-a culture that was first weaponized then chastened within the crucible of the European Reformations.
\end{abstract}

(C) JEFFREY D. BURSON, 2019 | DOI:10.1163/22141332-00603001

This is an open access article distributed under the terms of the prevailing CC-BY-NC license at the time of publication. 


\section{Keywords}

Jesuit(s) - Enlightenment - Counter-Enlightenment - Catholic Enlightenment Humanism - Reformations

In the 1779 edition of his Histoire philosophique de la religion, Abbé Claude Yvon (1714-89), the contributor to Denis Diderot's (1713-84) Encyclopédie, freemason, and controversial Catholic historian and apologist, extolled the Jesuits as "the Order that distinguished itself most by its zeal" because "the lawgiver of the Jesuits [Ignatius of Loyola $\left(c .1491-155^{6}\right)$ ], far from attempting to fence in the advantageous qualities with which nature has been pleased to adorn the minds of men, did not thus exclude any of his converts from them." Instead, Yvon continued, Ignatius permitted Jesuits "to embrace all arts," and as such, "the discernment of the mind [...] was one of the first laws comprising the code of his institute." This glowing review from someone considered by many in his day to have been a fairly heterodox Enlightenment author suggests that the history of the Jesuits during the age of Enlightenment is a far more complex and important story than early nineteenth-century retrospectives, which stress the Counter-Enlightenment proclivities of the order, would suggest. Although works on religious, specifically Catholic, and more specifically Jansenist, contributions to the Enlightenment abound, the contributions of the Jesuits to the Enlightenment have remained relatively unexplored since Robert R. Palmer

1 The full passage selectively quoted above reads as follows: "L'Ordre qui se distinque la plus par son zèle fut celui des Jésuites. Il n'y a qu'une voix sur la sagesse, l'art, \& la politique qui éleverent l'édifice de sa constitution. [...] Loin donc de renfermer dans l'étroite sphere de la scholastique, les qualités avantageuses dont la nature se plaît à orner les esprits, le Législateur des Jésuites n'en exclut aucune de ses proselytes; il leur permit d'embrasser tous les arts. Le Discernement des esprits, afin d'appliquer chacun à l'espece de travail qui lui seroit propre, fut une des premieres Loix qui composerent le code de son institute. Cette sage politique procura à la Société une foule d'excellents Sujets en tout genre, dont elle s'appropria les talens, \& qui asservirent son crédit en attendant leur reputation." Abbé Claude Yvon], Histoire philosophique de la Religion, 2 vols. (Liège: Clément Plomteux, Impriméur de messeigneurs les Etats, 1779), 2:46o-62. In the interest of remaining faithful to the texts themselves, and in so far as possible without inhibiting the comprehension of the reader, I have retained the orthography and spelling of the French texts as originally penned or published, here and throughout this introduction. For further details on the sense in which Yvon was considered heterodox in his day, and for a comprehensive synthetic redefinition of Enlightenment using Yvon's biography as its focal point, see Jeffrey D. Burson, The Culture of Enlightening: Abbé Claude Yvon and the Entangled Emergence of the Enlightenment (Notre Dame, IN: University of Notre Dame Press, 2019). 
initially identified the very real affinities between Jesuit thought and the emergence of the Enlightenment as long ago as $1939 .{ }^{2}$ Accordingly, this introduction, and the essays contained within the pages of this special issue of the Journal of Jesuit Studies, focus specifically on ways in which the individual Jesuits contributed to broader patterns of European intellectual and cultural history during the Enlightenment. Although the respective conclusions reached by the authors of each contribution differ, taken together, they explore different aspects to an important question: to what extent were individual Jesuits (at times, despite themselves, and at times, against the grain of the order's official positions) unlikely contributors to the Enlightenment.

The question of whether one might speak of a specifically Jesuit contribution to the Enlightenment is complicated in large measure because a sufficiently satisfactory consensus definition of the Enlightenment continues to elude scholars. ${ }^{3}$ The most common conventional formulation of the Enlightenment defines it as the generally (but not exclusively) eighteenth-century movement (or series of movements) that valorized universal natural rights and a cosmopolitan cultural outlook, promoted the improvement of human society through empirical modes of reasoning, assumed an expansive faith in the fruits of progress through natural philosophy, and advocated for enhanced toleration, secularization, and criticisms of established religious elites, all while engaging in projects of socio-political reform and philanthropy. If this definitionin so many ways inherited from the work of Peter Gay and reaffirmed in modified form by several recent works-is posited in toto, then clearly no

2 Robert R. Palmer, Catholics and Unbelievers in Eighteenth-Century France (Princeton: Princeton University Press, 1939); Palmer, "The French Jesuits in the Age of Enlightenment," American Historical Review 45, no. 1 (1939): 44-58; Catherine M. Northeast, The Parisian Jesuits and the Enlightenment, 1700-1762 (Oxford: The Voltaire Foundation, 1991); John M. Pappas, Berthiers Journal de Trévoux and the Philosophes (Geneva: Institut et Musée de Voltaire Les Délices, 1957); Jeffrey D. Burson, The Rise and Fall of Theological Enlightenment:Jean-Martin de Prades and Ideological Polarization in Eighteenth-Century France (Notre Dame: University of Notre Dame Press, 2010); Burson, "The Distinctive Contours of the Jesuit Enlightenment in France," in Exploring Jesuit Distinctiveness: Interdisciplinary Perspectives on Ways of Proceeding within the Society of Jesus, ed. Robert Aleksander Maryks (Leiden: Brill, 2016), 212-34; Daniel J. Watkins, "Enlightenment, Catholicism, Conservatism: The Isaac-Joseph Berruyer Affair and the Culture of Orthodoxy in France, c.1700-1830" (PhD diss.: Ohio State University, 2014).

3 This lack of historical consensus concerning the Enlightenment and its relevance to the role of the Jesuits in the Enlightenment is further discussed in Burson, "Distinctive Contours of the Jesuit Enlightenment in France," 211-16. 
Jesuit can be fully considered a scion of the Enlightenment. ${ }^{4}$ But the historiographical notion of a unitary Enlightenment has been far from the end of the story. For something approaching nearly forty years, scholars have been uncovering a far more extensive range of diversity among writers, philosophers, and publicists of the late seventeenth and eighteenth centuries. So great has been the scope of this pluralism that any tidy definition of a unitary Enlightenment has been strained to the breaking point, or risks being relegated to the margins of an increasingly expansive eighteenth-century cultural history that leaves as much out of the Enlightenment as it includes within it. In place of the singular Enlightenment, an illuminating but at times dizzying and contradictory assortment of enlightenments-radical, moderate, national, imperial, European, non-European, and religious - now abound. The study of so many plural enlightenments has broadened our understanding of the significance of the late seventeenth- and eighteenth-century period to world history while greatly contributing to the richness of the cultural, religious, and intellectual histories of the period. But the search for a still more capacious yet coherent definition of Enlightenment culture - a kind of useful grand unifying theory-continues. ${ }^{5}$

4 Peter Gay, The Enlightenment: An Interpretation: The Rise of Modern Paganism (New York: Alfred A. Knopf, 1967); Ernst Cassirer, The Philosophy of the Enlightenment, trans. Fritz C. A. Koellen and James P. Pettegrove (Princeton: Princeton University Press, 1951); more recently Anthony Pagden, The Enlightenment and Why It Still Matters (New York: Random House, 2013); John Robertson, The Case for the Enlightenment (Oxford: Oxford University Press, 2005); from a different and far more problematic perspective, see Steven Pinker, Enlightenment Now: The Case for Reason, Science, Humanism, and Progress (New York: Viking, 2018). On the cosmopolitan ethos arguably invented by the Republic of Letters during the Enlightenment, see Margaret C. Jacob, Strangers Nowhere in the World: The Rise of Cosmopolitanism in Early Modern Europe (Philadelphia: University of Pennsylvania Press, 2007).

5 A mere sampling of the most influential works that have pluralized the Enlightenment into national, religious, imperial, or radical variations include the following: J. G. A. [John Greville Agard] Pocock, Barbarism and Religion: The Enlightenments of Edward Gibbon, 1737-1764 (Cambridge: Cambridge University Press, 1999); Roy Porter and Mikláš Teich, eds., The Enlightenment in National Context (Cambridge: Cambridge University Press, 1981); David Sorkin, The Religious Enlightenment: Protestants, Jews, and Catholics from London to Vienna (Princeton: Princeton University Press, 2008); Shmuel Feiner, The Jewish Enlightenment, trans. Chaya Naor (Philadelphia: University of Pennsylvania Press, 2004); on the "Radical Enlightenment" see the four book series beginning with Jonathan I. Israel, Radical Enlightenment: Philosophy and the Making of Modernity, 1650-1750 (Oxford: Clarendon Press, 2001); on the trans-Atlantic dimensions of the Enlightenment, see Susan Manning and Francis Cogliano, eds. The Atlantic Enlightenment (London: Ashgate, 2007); for a fascinating and under-appreciated perspective on the prospects for globalizing the Enlightenment using the history of concepts, see 
Despite this increasingly fraught hunt for the Enlightenment - an undertaking that may at times seem like an endless safari in search of a unicorn-the prospect of a Jesuit contribution to the Enlightenment is nevertheless far more likely and timely because of two recent and fruitful historiographical trends. The first trend is the serious attention devoted in recent years to the existence of a "Catholic Enlightenment." This research has been advanced by a growing number of scholars across a variety of disciplines (history, philosophy, literary studies, historical theology), but by no one more zealously than the prolific scholar, Ulrich L. Lehner, who has recently synthesized the state of the field in his Catholic Enlightenment: The Forgotten History of a Global Movement (2016). ${ }^{6}$ Lehner's synthesis broadly defines "Catholic Enlightenment" as a coherent movement, forged primarily by Catholic clergy who aimed "to use the newest achievements of philosophy and science to defend the essential dogmas of Catholic Christianity by explaining them in a new language," and thereby "reconcile Catholicism with modern culture." ${ }^{7}$ But, growing recognition of the contributions made by Jesuits to Catholic scholarship during the Enlightenment, coupled with studies that emphasize the intensity of theological, philosophical, and personal disagreements within "Enlightened Catholicism" itself (in particular, that which prevailed between Jansenists and Jesuits who were both, arguably, heirs to what became very different "Catholic Enlightenments") have further problematized whatever coherence that even the Catholic Enlightenment might seem to have possessed. Jesuit Enlightenment, then, from the perspective of the more fractured and pluralized picture of seventeenth- and eighteenth-century Catholicism that emerges from Dale K. Van Kley's work, in particular, is conceived as almost entirely separate from the kind of Catholic Enlightenment that informed the philo-Jansenist purveyors of "Reformed Catholicism" - the ones most responsible for the suppressions of the Jesuits $(1759-73){ }^{8}$

Sebastian Conrad, "Enlightenment in Global History: An Historiographical Critique." American Historical Review 117, no. 4 (2012): 999-1027.

6 Ulrich L. Lehner, Catholic Enlightenment: The Forgotten History of a Global Movement (Oxford: Oxford University Press, 2016).

7 Lehner, Catholic Enlightenment, 7 .

8 Dale K. Van Kley, Reform Catholicism and the International Suppression of the Jesuits, 1550-179o (New Haven: Yale University Press, 2018); Van Kley, "Conclusion: Varieties of Enlightened Experience," in God in the Enlightenment, ed. William J. Bulman and Robert G. Ingram (Oxford: Oxford University Press, 2015), 278-316; Van Kley, "From the Catholic Enlightenment to the Risorgimento: The Debate between Nicola Spedalieri and Pietro Tamburini, 1791-1797," Past and Present 224, no. 1 (2014): 109-62; Van Kley, "Jansenism and the International Suppression of the Jesuits," in Enlightenment, Reawakening and Revolution, 1660-1815, The Cambridge History of Christianity 7, ed. Stewart J. Brown and Timothy Tackett (Cambridge: Cambridge 
The second fruitful historiographic tendency portending renewed attention to the Jesuits during the Enlightenment is the recent trend of situating the origins of secular Enlightenment - and of its eighteenth-century radicalization - within a much broadened chronological and cultural context. Many scholars have, thus, revisited continuities between eighteenth-century preoccupations and those of the sixteenth and seventeenth centuries. Ann Thomson has reminded us of the significance of earlier religious debates to the circulation of scientific materialism during the early eighteenth century; historians of philosophy such as Dennis Des Chene and Anthony Kenney have underscored the importance of early modern Scholasticism as prelude to the advances in natural philosophy portending Enlightenment; and controversies over the philosophical content of ancient Greco-Roman philosophies, or the primacy of ancients over the moderns, have received renewed attention as origins of the early Enlightenment in the diverse works of Neven Leddy, Avi Lifschitz, Alan C. Kors, Thomas M. Kavanagh, Anton M. Matytsin, and Dan Edelstein. ${ }^{9}$ These examinations of the cultural history of the Enlightenment as something that emerged from longer-term patterns of early modern scholarship invites renewed attention to the Jesuit contributions to Enlightenment for reasons

University Press, 2006), 302-28; Jeffrey D. Burson, "Introduction: Catholicism and Enlightenment, Past, Present, and Future," in Enlightenment and Catholicism in Europe: A Transnational History, ed. Jeffrey D. Burson and Ulrich L. Lehner (Notre Dame: University of Notre Dame Press, 2014), 1-39; also Burson, "The Catholic Enlightenment in France from fin de siècle: Crisis to Revolution, c. 1650-1789," in Companion to the Catholic Enlightenment, ed. Ulrich L. Lehner and Michael Printy (Brill: Leiden, 2010), 61-125.

9 Ann Thomson, Bodies of Thought: Science, Religion, and the Soul in the Early Enlightenment (Oxford: Oxford University Press, 2008; repr. 2010), 22-27, 229-37; Ann Thomson, L'âme de lumières: Le débat sur l'être humain entre religion et science Angleterre-France (1690-1760) (Paris: Epoques Champ Vallon, 2013); Dennis Des Chene, Physiologia: Natural Philosophy in Late Aristotelian and Cartesian Thought (Ithaca: Cornell University Press, 1996); Anthony Kenney, Essays on the Aristotelian Tradition (Oxford: Clarendon Press, 2001); Neven Leddy, and Avi S. Lifschitz, eds., Epicurus in the Enlightenment (Oxford: Voltaire Foundation, 2009); Alan C. Kors, Epicureanism and Unbelief in France, 1650-1729 (Cambridge: Cambridge University Press, 2015); Thomas M. Kavanagh, Enlightened Pleasures: Eighteenth-Century France and the New Epicureanism (New Haven: Yale University Press, 2010); Anton M. Matytsin, The Specter of Skepticism in the Age of Enlightenment (Baltimore: Johns Hopkins University Press, 2016); Dan Edelstein, The Enlightenment: A Genealogy (Chicago: University of Chicago Press, 2010), 1-19, 37-52; Edelstein, "The Aristotelian Enlightenment," in Let There Be Enlightenment: The Religious and Mystical Sources of Rationality, ed. Anton M. Matytsin and Dan Edelstein (Baltimore: Johns Hopkins University Press, 2018), 187-201; Dan Edelstein, "The Classical Turn in Enlightenment Studies," Modern Intellectual History 9, no. 1 (2012): 61-71. 
I will develop at length in what follows. ${ }^{10}$ But most crucially for the moment is the common tendency of these scholars to abandon the exclusive focus on the Enlightenment as an affair of the middle to late eighteenth century, and instead, to revisit (and at times significantly reconfigure) Paul Hazard's notion of the late seventeenth century as a long-term source of Enlightenment discourse. ${ }^{11}$ In so doing, this more recent scholarship has addressed the emergence of Enlightenment thought from an entangled web of debates in which confessional polemicists, theologians, missionaries, travelers, philosophers, physiologists, and philologists collectively engaged between the middle to late 1600 s and the 1700 s. $^{12}$

In the introduction to this special issue, I similarly stress the continuities binding Jesuits to these long-term patterns of cultural history that most scholars now identify as having given rise to the Enlightenment. Yet, rather than considering the Enlightenment as a series of transformative eighteenth-century debates rooted in the middle seventeenth century (as Israel does), or late seventeenth century (as Hazard did), I would like to suggest that Jesuit engagement with the Enlightenment is best understood if we anchor the emergence of the Enlightenment debates in the culture of late Humanism - a culture that was first weaponized and then chastened within the crucible of the European Reformations, both Protestant and Catholic. From a sixteenth-century Republic of Letters confined mostly to Europe and centered principally on the texts of the Greco-Roman ancients and on polemical debate in matters of religion, the learned culture of eighteenth century evolved into a far more global sphere

10 Burson, "Distinctive Contours of Jesuit Enlightenment in France," 221-22.

11 Paul Hazard, La crise de la conscience européenne, 1680-1715 (Paris: Librairie Arthème Fayard, 1961).

12 Among the many recent examples of such diverse work continues to proliferate, but see most notably William J. Bulman, "Introduction: Enlightenment for the Culture Wars," in God in the Enlightenment, ed. William J. Bulman and Robert G. Ingram (New York: Oxford University Press, 2016), 1-41; Jeffrey D. Burson, The Culture of Enlightening; Matytsin and Edelstein, eds., Let There Be Enlightenment; Alan C. Kors, Atheism in France, 1650-1729, vol. 1: The Orthodox Sources of Disbelief (Princeton: Princeton University Press, 1990); Kors, Naturalism and Unbelief in France, 1650-1729 (Cambridge: Cambridge University Press, 2015); Thomson, Bodies of Thought; for the long-term causes, impact, and debates concerning, the "Radical Enlightenment," see Steffen Ducheyne, "The Radical Enlightenment: An Introduction," in Reassessing the Radical Enlightenment, ed. Steffen Ducheyne (New York: Routledge, 2017); Jonathan I. Israel, "Radical Enlightenment': A Game-Changing Concept," in Reassessing the Radical Enlightenment, ed. Ducheyne, 15-47; Margaret C. Jacob, "The Radical Enlightenment: A Heavenly City with Many Mansions," in Reassessing the Radical Enlightenment, ed. Ducheyne, 48-6o. 
of critical debate about a variety of entangled subjects: everything from political thought and religious polemics, to political economy, moral philosophy, a nascent revolution in medical science, natural rights, and moral philosophy. When considered in this way, the culture of late Humanism, vital as much to the Jesuits as to other Catholics of the period, was effectively the midwife of eighteenth-century culture, and even of the secular Enlightenment. Far from being antithetical to questions of theology or religious faith, the secular Enlightenment was often the accidental progeny of religious debates. The scholarship and activities of the Jesuits often served as important catalysts for this process. $^{13}$

$\mathbf{1}$

\section{The Long Shadow of Humanism: Clashing Confessions and Moral Philosophy in the Emergence of the Enlightenment among the Jesuits}

The century of contentious religious polemics separating the death of Martin Luther (1483-1546) from the end of the Thirty Years' War left Catholics and Protestants with yawning chasms of irreparable difference concerning the sacraments, the nature of divine grace, ecclesiology and worship, and the nature of religious authority. Because these different understandings of divine revelation brokered no common basis for argumentation, nor any shared institutional authority capable of imposing resolution, Catholic and Protestant scholars sought to delegitimize one another by using ever more refined techniques of Renaissance textual criticism to discredit opponents by revealing analogies between the positions of their interlocutors and those of discredited past heresies. As religious polemics of this sort proliferated, lay and clerical writers thus threw themselves into theological argument that turned on increasingly sophisticated understandings of the history of philosophy. Meanwhile, confessional impulses and humanist textual erudition also began to inform the broadening of European mental horizons as a result of early modern globalization. The tremendous output of Jesuit missionary scholars played an instrumental role in this process, as they translated a world of Indigenous American, Chinese, Japanese, Indian, and Middle Eastern philosophies and religions, injecting them, thereby, into various scholarly and religious discussions that

13 For more a more detailed discussion of this argument, see chapters 1 and 12 of Burson, The Culture of Enlightening; cf. Damien Tricoire, "The Fabrication of the Philosophe: Catholicism, Court Culture, and the Origins of Enlightenment Moralism in France," EighteenthCentury Studies 51, no. 4 (2018): 453-77. 
would unfold throughout the 160os-170os. Although it was usually far from being the intention of the Jesuits themselves, the effect of such intercultural mediation and textual translation, in the hands of more radical philosophes and their late seventeenth-century precursors, was to provincialize the doctrinal disputes, foundational assumptions, and pious proclivities of the Europeans themselves. In this manner, therefore, the more polemical ecclesiastical histories of the seventeenth-century blossom into far more globalized, comparative histories of philosophy ("universal histories" in the parlance of the eighteenth century). In the aftermath of confessional conflict, globalized Renaissance historicism and the universal history of religion and philosophy came to inform attempts to reconstitute the socio-political order of confessional states by promoting civil peace and establishing epistemologically sound ways around the crisis of skepticism unleashed by the fracturing of theological consensus. ${ }^{14}$

Arguably, therefore, as Brad S. Gregory has suggested, reason and shared philosophical systems (Platonic, Aristotelian, Stoic, Epicurean, Cartesian, Leibnizian) somewhat ironically became the most viable ways to talk theology across confessions and sectarian divisions. By the eighteenth century, this same appeal to philosophy and rational argumentation led many Protestant and Catholic scholars - including many Jesuits - to be as to be as zealous for the advancement of natural philosophy, and as interested in the promotion of intellectual and moral improvement, as their some-time allies and some-time interlocutors among the philosophes. ${ }^{15}$

Another unlikely source of Jesuit Enlightenment derived from the late sixteenth- and seventeenth-century transformation of Catholic moral and confessional theology during the Catholic Reformation. Probabilism, as first articulated in 1577 by the Dominican Bartolomé de Medina (1527/28-80), broke with earlier moral theology by concluding that, if one is presented with a choice between two probable and authoritative opinions about how one might avoid sin, and one of the opinions is more probable than the other, one can nevertheless follow the less probable opinion without fear of sin. In other words, to choose, in good faith, a course of action based on faulty reasoning was arguably no sin at all. Medina's probabilism quickly found favor with leading Spanish Jesuits including Gabriel Vázquez (1551-1604) and

14 For the summary of the trajectory of sixteenth- and seventeenth-century religiophilosophical polemics in the first long paragraph of this section above, I am relying upon Bulman, "Introduction: Enlightenment for the Culture Wars," 15-19.

15 Brad S. Gregory, "The Reformation Origins of the Enlightenment's God," in God in the Enlightenment, 201-14, here 205-6; Gregory, The Unintended Reformation: How a Religious Revolution Secularized Society (Cambridge, MA: Harvard University Press, 2012). 
Francisco Suárez (1548-1617), at least in part, because it helped bridge the inevitable imperfections of speculative reason in a way that would allow for a kind of workaday pragmatic certainty necessary for action. But, as the seventeenth century progressed, the scope of what might be considered by Catholic texts of moral philosophy to be a probable opinion broadened, often at the behest of Jesuit confessors, and in ways that later afforded considerable fodder to antiJesuit critics. ${ }^{16}$ But, if the early eighteenth century was to be an age of practical reason as Matytsin has argued, ${ }^{17}$ as well as an age that valorized utilitarian morality, then arguably it was Jesuit probabilism that helped pave the way by popularizing a species of pragmatism within moral theology. Yet, as Dale Van Kley and Robert Maryks have diversely implied, Jesuit probabilism also emerged under the influence of the same humanistic rhetoric that impelled so much else about their participation in the age of Enlightenment. ${ }^{18}$

Both Jesuit moral theology, and the globalization of their deployment of humanist erudition, drew many scholars of the Society toward a relatively more optimistic appraisal of the consequences of the Biblical fall from grace described in Genesis. If the Christian doctrine of original sin could be explained as God's withdrawal of his perfective efficacious grace, then the essence of human nature was, in effect, unvarnished and capable of improvement: human nature might still be conceived as improvable through textual study and natural philosophy, as well as by supernatural revelation and the sacraments of the Catholic Church. Without supernatural grace, natural reason and the will could be considered as having become dependent on the senses, senses that were at once the locus of human corruptibility (morally, intellectually, and

16 Jean-Louis Quantin, “Catholic Moral Theology, 1550-180o," Oxford Handbook of Early Modern Theology, c. 1600-180o, ed. Ulrich L. Lehner, Richard A. Muller, and Anthony G. Roeber (Oxford: Oxford University Press, 2016), 122-25; for moral laxism and anti-Jesuitism, see Van Kley, Reform Catholicism, 71-89; and Stefania Tutino, Uncertainty in Post-Reformation Catholicism: A History of Probabilism (Oxford: Oxford University Press, 2017).

17 Matytsin, Specter of Skepticism, 268-74.

18 Robert A. Maryks, Saint Cicero and the Jesuits: The Influence of the Liberal Arts on the Adoption of Moral Probabilism (Aldershot, UK: Ashgate, 2008); Harro Höpfl, Jesuit Political Thought: The Society of Jesus and the State, c. 1540-1630 (Cambridge: Cambridge University Press, 2004), 15; John W. O'Malley, The First Jesuits (Cambridge, MA: Harvard University Press, 1995), 145; Dale K. Van Kley, "Setting the Scene: The Roman Archetto and Its French Connection in the Making of the International Campaign against the Jesuits," in Memoria de la expulsión de los jesuitas por Carlos III, ed. Immaculata Fernández Arrillaga, Verónica Mateo Ripoll, Manuel Pacheco Albalate, and Rosa Tribaldos Soriana (Madrid: Grupo Anaya, 2018), 29-39. 
socially), and, when properly instructed, a source of grace and enlightenment through diligently pursued study of ancient wisdom, and of nature itself. ${ }^{19}$

Thus, for reasons already deeply anchored in their moral theology, and in their belletristic pursuits inherited from the Renaissance, many Jesuits became important participants in the European Republic of Letters. Like many academicians and polymaths of the day, they too shared a faith in the capacity of advancements in natural philosophy, mathematics, and the liberal arts to improve and edify society. Thus, almost from their inception, Jesuits lionized education and scholarship as vital components of their apologetical and missionary endeavors on behalf of the Catholic Church. In speaking of Jesuit missionary successes in China, and of the Society's near hegemonic role in the education of the elites of Catholic Europe, René-Joseph Tournemine (16611739), editor of the Jesuits' premier eighteenth-century journal, Mémoires de Trévoux, spoke of the workings of divine grace in the following terms: "It is always grace that converts, but grace has more than one manner of achieving its ends, and it is in making oneself all [things] to all [people] that one finds, at last, that to which grace has attached the salvation of all." ${ }^{20}$ While Jesuits believed that salvific divine grace came by the will of God through the mysteries and sacraments of the Catholic Church, many in the Society of Jesus were enculturated to believe that careful study was a work of piety and social consciousness. To converse with academicians and natural philosophers about the wonders of nature empirically discerned; to discourse with humanists about the Greco-Roman ancients; to conduct oneself as a scholar-gentry at the court of the Son of Heaven in Beijing about Chinese ancient luminaries; or to engage in the rapidly changing intellectual sociability associated with the salons, clubs, and academies of the early Enlightenment—in short, to be "all to all"was a distinctively Jesuit approach to promoting the Catholic faith. This distinctive emphasis, often referred to as Jesuit "accommodationism," could and did mirror the wider processes by which the world of the "waning renaissance" became the culture that gave birth to the Enlightenment. ${ }^{21}$

19 Palmer, Catholics and Unbelievers, 117-25; Jean Ehrard, L'Idée de la nature en France dans la première moitié du XviIIe siècle (Geneva: Slatkine, 1981; 1969), 438-40; Northeast, Parisian Jesuits, 217-18; Burson, "Distinctive Contours of Jesuit Enlightenment in France," 219-20.

"C'est toujours la grace qui convertît, mais la grace a plus d'une manière d'arriver ses fins et c'est en se faisant tous à tous, qu'on trouve enfin à quoy c'est qu'elle a attaché le salut de tous." [Tournemine], "Discours sur les Etudes de la Compagnie," BnF, Nouvelles acquisitions françaises 10946, 366 .

21 For more on Jesuit accommodationism, see Florence C. Hsia, Sojourners in a Strange Land: Jesuits and Their Scientific Missions in Late Imperial China (Chicago: University of Chicago Press, 2009); Martin A. Lynn, The Jesuit Mind: The Mentality of an Elite in Early Modern 


\section{Jesuit Missionary Scholarship: Crucible of Jesuit Erudition between Humanism and Enlightenment}

Accommodationism originated in the Society's Christian Humanism and belletristic pursuits, but it also shaped the participation of many Jesuits in the construction of early Enlightenment culture. Accommodationism, this crucible of the transformation from late Humanism to the early Enlightenment, is most evident from within the scholarship produced by their extensive global missions. A cornucopia of field work, translations of classic texts, and cultural descriptions abound from their missions in South America, India, China, and elsewhere. ${ }^{22}$ The scholarly output of the Jesuit missionaries, and the diverse intellectual genealogies of which they became a part, illustrate a defining feature of Jesuit contributions the Enlightenment: namely, their polyvalence. As Pocock has suggested in a seminal essay on early modern intellectual history, the very same text can often be appropriated quite differently by a variety of different historical actors, and in ways that often belie or contradict the original text's context, or the intent of its authors. ${ }^{23}$ Nowhere is the polyvalent

France (Ithaca: Cornell University Press, 1988); O'Malley, First Jesuits; Burson, "Distinctive Contours of Jesuit Enlightenment in France," 216-18; for "waning renaissance," see William J. Bouwsma, The Waning of the Renaissance, 1550-1640 (New Haven: Yale University Press, 2000), x, 112-13, 151; on the rootedness of Enlightenment culture in Renaissance, see Jeffrey D. Burson, "An Intellectual Genealogy of the Revolt against 'Esprit de système' from the Renaissance to the Early Enlightenment," Historical Reflections/Réflexions historiques 44 , no. 2 (2018): $22-45$.

22 Burson, "Distinctive Contours of Jesuit Enlightenment in France," 226; Donald F. Lach and Edwin J. Van Kley, Asia in the Making of Europe, 3 vols. (Chicago: University of Chicago Press, 1993), 3:1676-87, 1731-48, 1752-53; Jesuit missionaries emerge as important cultural mediators in Jürgen Osterhammel, Unfabling the East: The Enlightenment's Encounter with Asia (Princeton: Princeton University Press, 2019); Alexander Statman, "A Global Enlightenment: History, Science, and the Birth of Sinology" (PhD diss.: Stanford University, 2017); David Mungello, Great Encounter of China and the West, 1500-180o (Lanham, MD: Rowman \& Littlefield, 1999); David Porter, Ideographia: The Chinese Cipher in Early Modern Europe (Stanford: Stanford University Press, 2001); Guy Stroumsa, New Science: The Discovery of Religion in the Age of Reason (Cambridge: Harvard University Press, 2010), 77-100, 145-49; David Allen Harvey, The French Enlightenment and Its Others: The Mandarin, the Savage, and the Invention of the Human Sciences (Basingstoke: Palgrave Macmillan, 2012).

23 J. G. A. Pocock, "Languages and Their Implications," in Politics, Language, and Time: Essays on Political Thought and History (New York: Cambridge University Press, 1971), 3-41; for a similar approach to the legacy of René Descartes and the polyvalence of Cartesianism, see most recently Tad M. Schmaltz, Early Modern Cartesianisms: Dutch and French Constructions (Oxford: Oxford University Press, 2017), notably 1-14; for more extensive 
appropriation of Jesuit texts more evident than in the history of Jesuit missionary scholarship.

One example of such polyvalence is afforded by the fate of Jesuit scholarship associated with China. Imbued with the Christian assumption that all humanity had once possessed the same natural revelation of the one true God before original sin had led to humanity into idolatry, Jesuits fashioned themselves after the scholar gentry of the late Ming and early Qing Dynasties. These Jesuits, armed with fluency in Chinese, deployed their humanistic acumen in a quest for the ways in which sources of Chinese antiquity displayed traces of divine revelation before the descent into idolatry, and thereby foreshadowed the New Testament gospels. The goal was, essentially, to "domesticate" the foreign religion of European Christianity by making it appear as the natural fulfillment of ancient Chinese Confucianism. At its most radical extreme, Jesuit Figurists such as Joachim Bouvet (1656-1730) went so far as to claim, in publications also read in Europe, that one of the mythological early Chinese rulers revered by Confucius, Fu Xi, was the Old Testament Patriarch, Enoch, who had bequeathed laws based in God's original revelation to the Israelite patriarchs by way of Noah after the Flood. However, in the hands of Jesuit Vicente Mascarell (fl. early 1700s), the idea that the original true religion of God might have been transmitted unsullied through Enoch to Confucius and preserved intact within Chinese thought for centuries seemed to leave open the possibility of universal salvation beyond explicit faith in Jesus Christ. ${ }^{24}$ Jesuit translations of Chinese thought, as well as their commentaries and debates over the nature of Chinese history, religion, or the Confucian rites also ended up producing a common source base for Voltaire (1694-1778), Herder (1744-1803), and anti-philosophe apologists like Nicolas-Sylvestre Bergier $(1718-90) .{ }^{25}$

discussion of the polyvalence of Jesuit Enlightenment, see Jeffrey D. Burson, "Between Power and Enlightenment: The Cultural and Intellectual Context for the Jesuit Suppression in France," in The Suppression of the Jesuits in Global Context: Causes, Events, and Consequences, ed. Jeffrey D. Burson and Jonathan A. Wright (Cambridge: Cambridge University Press, 2015), 45-51.

24 For this account of the implications of Figurism, see Lehner, Catholic Enlightenment, 116-17, and 116-17n29-30; on Figurism, see David E. Mungello, Curious Land: Jesuit Accommodation and the Origins of Sinology (Honolulu: University of Hawaii Press, 1989); for the most recent account of the Jesuit mission in China in English-language historiography, see Liam Matthew Brockey, Journey to the East: The Jesuit Mission to China, 1579-1624 (Cambridge, MA: Belknap Press, 2007).

25 Stroumsa, New Science, 77-100, 145-49; Lach and Van Kley, Asia in the Making of Europe, 3:1676-87, 1731-48; François-Marie Arouêt (Voltaire), Essai sur les moeurs et l'esprit des nations et des nations et sur les principaux faits de l'histoire depuis Charlemagne jusqu'à 
Sources that had originally emerged from attempts by Jesuit missionaryscholars to discover a locus classicus of primitive monotheism capable of facilitating the conversion of the Chinese, Algonquin-speaking Americans, Mesoamericans, or Indians were indeed readily redeployed by deists who believed that religious elites had corrupted the natural religion of humanity. This fundamentally deistic message was at the heart of the widely read compendium, Cérémonies et coutumes religieuses de tous les peuples du monde (Religious ceremonies and customs of all peoples of the world) published by Jean Frédéric Bernard (1683-1744) and Bernard Picart (1673-1733). The fourth volume of the latter work contained eighty pages of text and fourteen engravings closely derived from Jesuit sources, specifically Martino Martini's (1614-61) Sinicae historiae (1658), Philippe Couplet's (1623-93) Confucius Sinarum philosophus (1687), Louis Le Comte's (1655-1728) Nouveaux mémoires sur l'état present de la Chine (1696), Athanasius Kircher's (1602-80) China illustrata (1667), and selections from Charles Le Gobien's (1652-1708) Lettres édifiantes et curieuses $(1702-76) .{ }^{26}$ Moreover, it was by using Jesuit missionary texts that even more ardent radical naturalists such as the novelist and libertine, Jean-Baptiste Boyer, Marquis d'Argens (1704-71), went well beyond the deists by using the ancient Chinese cosmology as evidence that the prisca theologia (pristine and original theology) of humankind was originally materialist and proceeded from the assumption that matter was capable of self-creation and adaptation. At times, nevertheless, more radical writers had only to reframe the implications of what some of the Jesuits had, themselves, asserted, for it was none other than Ricci's successor, Niccolò Longobardi (1559-1654), who, for very different reasons, was

Louis XIII, 3 vols., in Oeuvres complètes de Voltaire, ed. Theodore Beuchot, new ed. (Paris: Garnier, 1878), 11:176-77; Johann Gottfried von Herder, Outlines of a Philosophy of Man, trans. T. Churchill (London: Bergman, 1966; Leipzig: Johann Friedrich Hartoch, 1784), 292; Clorinda Donato, "Le Nouveau Monde et l'apologie du catholicisme dans le Dictionnaire de théologie (1789-179o) ed. abbé Bergier," Tangence 72 (2003): 57-73; Nicolas-Sylvestre Bergier, Origine des dieux du paganism et le sens des fables découvert par une explication suivie poesies d'Hésiode, 2 vols. (Paris: Humblot, 1767); 1:38-44; Bergier, La certitude des preuves du Christianisme, ou Réfutation de l'Examen critique des apologists de la Religion chrétienne, 2 vols. (Paris: Humblot, 1767), 1:216; Jeffrey D. Burson, "Nicolas-Sylvestre Bergier (1718-1790): An Enlightened Anti-Philosophe," in Enlightenment and Catholicism in Europe: A Transnational History, ed. Burson and Lehner, 68-88.

26 Wijnand Mijnhardt, "Jean Frédéric Bernard as Author and Publisher," in Bernard Picart and the First Global Vision of Religion, ed. Lynn Hunt, Margaret C. Jacob, and Wijnand Mijnhardt (Los Angeles: Getty Research Institute Publications, 2010), 17-34; Marcia Reed, "Bernard Picart on China: 'Curious' Discourses and Images Taken Principally from Jesuit Sources," in Bernard Picart and the First Global Vision of Religion, 216. 
among the first Jesuits to question whether ancient Chinese texts spoke of an anthropomorphic deity at all. ${ }^{27}$ Because of the polyvalence of Jesuit texts, and "though they were unlikely to admit it," as Jonathan A. Wright has recently summarized, "many of the champions of the radical French Enlightenment owed considerable debts to their Jesuit educations and the legacy of Jesuit scholarship."28

Michela Catto's contribution further delves into the ways in which Jesuit arguments in one rhetorical context circumscribed by their apologetic and missionary concerns effectively gave rise to innovative conclusions capable of later use by deists and atheists seeking to subvert the Jesuits' raison d'etre. Catto argues that, in defending themselves against accusations that Jesuit missionaries were tacitly condoning idolatry by permitting Chinese Christian converts to participate in traditional rites (imperial state rituals, rites honoring Confucius, and family sacrifices honoring one's ancestors), the Jesuit JosephAntonio Provana (1662-1720) argued that the church should take seriously the Chinese emperor's own explanation of the Chinese Rites before rushing into condemnation. The implications of Provana's argument nevertheless effectively decentered traditional European Catholic theological paradigms by implying that those who practice a "pagan" cultural tradition (such as the Chinese Rites) should speak for themselves as the basis for adjudging that tradition's orthodoxy or heterodoxy. In her most original argument, Catto further contends that, despite the prevailing headwinds of theological censorship ever more constantly blowing against them, Parisian Jesuits nonetheless tacitly continued to defend their position on Chinese accommodationism in the pages of the Mémoires de Trévoux, particularly under the editorial oversight of René Joseph Tournemine. Ultimately, in response to further debates within the early eighteenth-century Republic of Letters over the nature of the Chinese Rites, and to the possibility that China might afford evidence that a society governed

27 Jean-Baptiste Boyer, le marquis d'Argens, Lettres chinoises, ou correspondence philosophique, historique et critique entre un chinois voyageur et ses correspondans à la Chine, en Moscovie, et au Japon, 6 vols., new ed. (La Haye: Pierre Paupie, 1769), 1:138-39; on Chinese materialism and the "Radical Enlightenment" see Jonathan I. Israel, "Admiration of China and Classical Chinese Thought in the Radical Enlightenment (1685-1740)," Journal of East Asian Studies 4, no. 1 (2007): 1-25; and Israel, Enlightenment Contested (Oxford: Clarendon Press, 2006), 640-42; for further discussion, see Burson, "Distinctive Contours of Jesuit Enlightenment," in Exploring Jesuit Distinctiveness, 227-30.

28 Jonathan A. Wright, "Ruggiero Boscovich (1711-1787): Jesuit Science in an Enlightenment Context," in Enlightenment and Catholicism in Europe, 364; Marc Fumaroli, "The Fertility and Shortcomings of Renaissance Rhetoric: The Jesuit Case," in Jesuits: Cultures, Sciences, and the Arts, 100. 
by morally-upright atheists could exist, Tournemine parried with a rather surprising argument in Réflexions sur l'athéisme attribué à quelques peuples par les premiers missionnaires qui leur ont annoncé l'Evangile (Reflections on atheism attributed to some peoples by the first missionaries who announced the Gospel to them). In this work, Tournemine argued that true atheism simply did not exist. As he concluded, even those philosophers (such as the so-called "neo-Confucian" scholar elites of eighteenth-century China) who conceived of the cosmos in material terms nevertheless venerated an intelligent and vitalistic force inhering within the cosmos. Accordingly, as Catto suggests, modern notions of atheism were significantly reinvented by early modern Jesuits whatever their intentions may have originally been.

The extensive scholarship on the Jesuit missionary scholars in China, to which Catto's article contributes, illustrates the ironic implications of Jesuit humanist erudition in the emergence of the Enlightenment. Such ironies as individual Jesuits showing up as accidental sources for more radical freethinkers by virtue of their role in redefining concepts like atheism further suggests that historians should not overlook the role of individual Jesuits in the emergence even of the so-called radical Enlightenment. As in the case of China, recent historical scholarship on Jesuits in India has similarly begun to uncover how the globalized humanism practiced by Jesuit missionary scholars played an unlikely and ironic role in the origins of Enlightenment debates. At the behest of Roberto de' Nobili (1577-1656), many Jesuits lived like members of the traditional caste of scholars and priests known as the Brahmins and applied themselves to learning the most ancient of sacred Vedic texts in Sanskrit. Jesuit missionary scholars ultimately sought to demonstrate that the New Testament was, itself, a lost Vedic text that held the key to mysteries contained within all the others. Although this Indian accommodationism was quite successful from the perspective of the Jesuits (insofar as the it sparked conversions among a number of Brahmins), it was increasingly questioned after 1704 when the papacy grew wary of the possibility that too many Hindu customs might be gaining tacit sanction. Many aspects of Indian accommodationism, like the accommodationism at the heart of the Chinese Rites controversy, were finally suppressed by Benedict XIV (r.1740-58) in $1744^{29}$

Just as in the case of China, as Joan-Pau Rubiés has recently argued, Jesuit missionary accommodationism involved a barrage of study, translation, and abridgment of Indian texts. So much so, in fact, that both Rubiés's work and the contribution by Carolina Armenteros in this issue have situated Jesuit missionary scholarship at the origins of European Indology itself. Most works 
of Jesuit Indology were never intended for European audiences during the early seventeenth-century apex of Counter-Reformation censoriousness. But, by the late seventeenth century, much of this earlier Jesuit missionary Indology began to circulate alongside texts by lay philosophers, travelers, and Protestant scholars. Among the key moments in this continental circulation of earlier Jesuit work on Indian religion was the publication of Athanasius Kircher's China illustrata (1667). Kircher abridged much earlier field research done by Jesuit missionaries, including research into Sanskrit texts accomplished by German Jesuit Heinrich Roth (1620-88) in Agra, in order to argue that the religion of the Brahmins derived from the march of idolatry from Egypt to India-an origin story of idolatry that, Kircher thought, also explained the adoption of Buddhism in China and Japan. Kircher's China illustrata, as Rubiés has asserted, was transitional: it redeployed Jesuit scholarship originally designed to accommodate indigenous traditions in order to facilitate conversion, but for the purpose of placing Indian religion within the context of a more universal history of religion..$^{30}$

But, Kircher's China illustrata proved to be a harbinger of the early eighteenth-century preoccupation with Indian religion that swept the European Republic of Letters. This early fascination with India-shared by readers of Protestant, Catholic, and lay travelers - was characterized by the far more direct and frequent influence of texts produced by Jesuit missionary scholars on European discourse about India. Much of this field work derived from the Jesuit missionaries in Northern India, those in Coromandel, and those spearheaded by Nobili and based along the Malabar Coast. In this same period, Jesuit missionary observations of Hinduism achieved broad circulation in Europe thanks to Le Gobien's Lettres édifiantes et curieuses first published in 1702, and Jesuit missionaries in Southern India learned Tamil and Telugu with such mastery as to write Christian literature in those languages. ${ }^{31}$ To a considerable extent, as Rubiés's work has shown, the intermingling of Jesuit missionary scholarship on Hinduism (and on other Asian religious cultures) with Protestant texts, and with travelers' narratives, engendered a fascination with the origins of idolatry and the history of human religion as an object of study in its own right. The process unleashed by the application of Jesuit humanist erudition to non-European ancient texts, thus, effectively globalized the sixteenth- and seventeenth-century genre of sacred history, and impelled an eighteenth-century fascination with the genre of universal history. Ironically,

\footnotetext{
30 Joan-Pau Rubiés, "From Christian Apologetics to Deism: Libertine Readings of Hinduism, 1650-1730," in God in the Enlightenment, 107-10.

31 Rubiés, "From Christian Apologetics to Deism," 110-12.
} 
Jesuit Enlightenment, the origins of which were undertaken within a largely apologetic and missionary context, paradoxically became a means by which "a variety of competing Christian apologetic traditions actually encouraged the emergence of anti-Trinitarian creeds, as well as wider attacks on all religion as superstition." 32

The contribution to this issue by Carolina Armenteros similarly focuses on the long-term significance of Jesuit missionary scholarship on India in the creation of the discipline of anthropology. In this contribution, Armenteros provides a wealth of historical context for the development of Jesuit missionary texts on India, ultimately focusing on the publication of Mores and Customs of the Indians (1777), a work that became "the first treatise of Indology and a classic of early anthropology." For nearly two centuries, during which time it was reprinted multiple times and was widely read, the work's Jesuit authorship remained obscure, but Armenteros's essay purports to demonstrate, not only that this work was anchored in Jesuit perceptions of Indian culture, but that it was also very much the product of a vast trove of literature about Indiaa kind of early anthropological "field work" - created by Jesuit missionaries among the diverse cultures of the Indian Subcontinent throughout approximately two centuries of its missionary activities. To the extent that Armenteros considers Jesuit proto-anthropology to be at all a part of the Enlightenment, however, it is work "aligned more readily with conservative enlightened rather than with mainstream enlightened sensibilities." Armenteros's use of the term "mainstream enlightened sensibilities" in this contribution is more capacious than Jonathan Israel's "moderate mainstream." ${ }^{33}$ In a way that is arguably reminiscent of Peter Gay's definition of the Enlightenment as a whole, Armenteros defines those with "mainstream enlightened sensibilities" as the anti-clerical, secularizing writers and publicists of the mostly French Enlightenment (Voltaire for example) with the addition of others such as Johann Gottfried von Herder (1744-1803) — a mainstream that, in Armenteros's view, informed those who claimed a monopoly on the foundation of sociology, anthropology, and so many human sciences in the nineteenth century. Armenteros considers Jesuit Indologists, on the other hand, as having been associated with a more conservative variety of Enlightenment, in a way that dovetails with recent attempts

32 Rubiés," Libertine Readings of Hinduism," 111-13, and for quote, see 113; for complimentary interpretations of this process, see Stroumsa, New Science, 1-13.

33 For "moderate mainstream," see Jonathan I. Israel, Enlightenment Contested: Philosophy, Modernity, and the Emancipation of Man, 1670-1752 (Oxford: Oxford University Press, 2006), 37-38; Carolina Armenteros, "The Enlightened Conservatism of the Malabar Missions: Gaston-Laurent Cœurdoux (1691-1779) and the Making of an Anthropological Classic," Journal of Jesuit Studies 6 (2019): 439-66, here 442, 464-65. 
to define "Enlightenment Conservatism" by Dale K. Van Kley, Mark Curran, and Mircea Platon. ${ }^{34}$ Armenteros argues that the Jesuits Indologists she studies crafted an enlightened conservative perspective rooted in the enhanced global understanding produced by the missionaries' engagement with the texts and contexts of Indian culture. Her contribution reaches a compelling and original conclusion worthy of further study: that the origins of anthropology, far from having been due strictly to the secular authors and scientific travelers usually associated with the late Enlightenment, were just as much the product of painstaking work by Jesuit missionaries. Armenteros's further contention that this process further reveals the global and Jesuit origins of a distinctive "enlightened conservatism" will no doubt also provoke further scholarly discussion. The extent to which Jesuit "enlightened conservatism" reveals, as Armenteros maintains, a "non-European ancestry of social and political conservatism," or implies a closer connection between Jesuit proto-anthropology, enlightened conservatism, and what other scholars have referred to as the "Counter Enlightenment" is a matter of debate. ${ }^{35}$ But, there is no doubt that Armenteros's insightful and erudite contribution reveals much about how "early ethnography and field anthropology" among Jesuits "enhances our understanding not only of anthropology's non-European origins," and casts light on the variegated spectrum of the Enlightenment itself. ${ }^{36}$

\section{Jesuit Natural Science in an Age of Enlightenment}

The development of Jesuit science has received considerably more scholarly attention in recent years. ${ }^{37}$ As Jesuits conceived it, the observation, classification,

34 See for "Enlightenment Conservatism" and "Conservative Enlightenment" in Dale K. Van Kley, "From the Catholic Enlightenment to the Risorgimento: The Debate between Nicola Spedalieri and Pietro Tamburini, 1791-1797," Past and Present 224, no. 1 (2014): 109-62; Mircea Platon, “'Touchstones of Truth': The Enlightenment of J.-B.-L. Gresset, L.-M. Deschamps, and S.-N.-H. Linguet" (PhD diss., Ohio State University, 2012); Mark Curran, Atheism, Religion and the Enlightenment in Pre-Revolutionary Europe (Suffolk, UK: Boydell \& Brewer, 2012).

35 Armenteros, "The Enlightened Conservatism of the Malabar Missions," 1-2, 442-44, 465; and for the most significant recent scholarship on "Counter Enlightenment," see Darrin M. McMahon, Enemies of Enlightenment: The French Counter-Enlightenment and the Making of Modernity (Oxford: Oxford University Press, 2001); Carolina Armenteros, The French Idea of History:Joseph de Maistre and His Heirs, 1794-1854 (Ithaca: Cornell University Press, 2011).

36 Armenteros, "The Enlightened Conservatism of the Malabar Missions," 1, 444, 464.

37 Recent work concerning Jesuit science in the seventeenth and eighteenth centuries include O'Malley, et al., eds., Jesuits: Cultures, Sciences, and the Arts, 1540-1773; O'Malley, 
and greater apprehension of nature was a pious act of moral edification descended from the Renaissance ideal of the vir virtutis (man of virtue), premised on the need to supplement and correct knowledge derived from ancient texts, and purposed for the moral improvement of society. This intersection of piety and pedagogy mirrored the wide-ranging sacred and secular erudition of figures such as Gottfried Wilhelm Leibniz (1646-1716) and René Descartes (1596-1650); it was no less kindred to the ideal of the scholar-missionary that had enervated the scientific endeavors and pious pursuits of Jesuits overseas. ${ }^{38}$

Jesuits throughout Europe actively participated in, and popularized, the fruits of the new natural philosophy. Beyond the well-known role of the Mémoires de Trévoux in reviewing and disseminating major works of natural philosophy, Jesuit professors such as Claude-François des Granges (1722-92) introduced students in Toulouse to the works of Daniel Bernoulli (1700-82), Christiaan Huygens (1629-95), Mme. Emilie de Châtelet (1706-49), and Claude Adrien Helvétius (1715-71) in 1758. Just a few years later, in 1763, Aimé-Henri Paulian (1722-1801) published an extensive critical dictionary throughout which he abridged the most significant works of experimental physics and natural philosophy for use by teachers in remote towns and small cities lacking in provincial academies or libraries. Methods of physics instruction in the roughly forty Parisian colleges of the Jesuits similarly influenced students and professors at other institutions, including the University of Paris. ${ }^{39}$ In general,

et al., eds., The Jesuits, vol. 2: Cultures, Science, and the Arts, 1540-1773 (Toronto: University of Toronto Press, 2002); Christian Albertan, "Entre foi et sciences: Les Mémoires de Trévoux et le mouvement scientifique dans les années 50," Dix-huitième siècle 34 (2002): 91-97; portions of J. B. [John Bennett] Shank, The Newton Wars and the Beginning of the French Enlightenment (Chicago: University of Chicago Press, 1995); Mordechai Feingold, ed., Jesuit Science and the Republic of Letters (Cambridge, MA: MIT Press, 2002); Marcus Hellyer, Catholic Physics: Jesuit Natural Philosophy in Early Modern Germany (Notre Dame: University of Notre Dame Press, 2005); see also Sheila J. Rabin, "Early Modern Jesuit Science: A Historiographical Essay," Journal of Jesuit Studies 1, no. 1 (2014): 88-104; also of note as a "digital prosopography on Jesuit scholars in the early modern sciences, encompassing the period between the foundation of the Society of Jesus in 1540 and the first few decades after its suppression in 1773" is "The Jesuit Science Research Network," compiled by Dagmar Mrozik, and Volker Remmert, housed at the Interdisciplinary Centre for Science and Technology Studies at Wuppertal University, www.jesuitscience.net (accessed January 15, 2019).

38 Matthew L. Jones, The Good Life in the Scientific Revolution: Descartes, Pascal, Leibniz, and the Cultivation of Virtue (Chicago: University of Chicago Press, 2006); Hsia, Sojourners in a Strange Land.

39 Burson, "Between Power and Enlightenment," 53-55; René Taton, ed., Enseignement et diffusion des sciences en France au XVIIIe siècle (Paris: Herman, 1964), 38, 44, 49, 61-62, 130, 
as Jonathan A. Wright has aptly reminded us, the very fact that by $c .1700$ the Jesuit order managed approximately seven hundred colleges and universities throughout Europe, in addition to two dozen astronomical observatories, makes their likely impact on the unfolding and popularization of the scientific revolution of utmost importance to scholars of the period. ${ }^{40}$

In ways that transcended popularization and pedagogy, however, Jesuits often proved themselves to be active and original participants in the scientific culture of the eighteenth-century. Working with a fellow Jesuit, Christophe Maire (1697-1767), Ruggiero Boscovich (1711-87), for example, helped advance eighteenth-century understanding of the true shape and size of the earth by gathering data suggesting that the planet was an oblate sphere. Born Ruđer Bošković in Dubrovnik, Boscovich, as he would be more commonly known in the Republic of Letters, became a professor of mathematics at the Collegio Romano in 1740 after publishing his first of his major works on Newton. Boscovich studied an impressively vast array of scientific questions of interest to eighteenth-century readers: the nature of the Aurora Borealis, sunspots, and the transit of Mercury, for example. By 1758, Boscovich published Theoria philosophiae naturalis (The theory of natural philosophy). Although it was initially of relatively little importance to eighteenth-century readers, Boscovich's Theoria has been hailed in retrospect as a highly original harbinger of atomic theory that was cited by James Clerk Maxwell (1831-79), Michael Faraday (17911867), and even Albert Einstein (1879-1955). Although Boscovich antagonized Jean le Rond d'Alembert (1717-83) in ways that harmed his reputation among Paris scientists and philosophes, and despite the fact that many of his theories engendered opposition from his superiors at the Collegio Romano, Boscovich nevertheless became a corresponding member of the French Academy of Sciences in 1748, a member of the Royal Society in 1761 , and eventually, a member of, both the Roman Accademia degli Arcadi, and the St. Petersburg Academy. ${ }^{41}$ Beyond Boscovich's original contributions to theoretical physics discussed above, he greatly contributed to improvements in lenses and other scientific instruments in his later years, while additionally enhancing Western European perspectives on Eastern Europe, and fostering greater Jesuit appreciation of

147; Laurence W. B. Brockliss, French Higher Education in the Seventeenth and Eighteenth Centuries: A Cultural History (Oxford: Clarendon Press, 1987), 185-9o, 352-55, 363-69; Burson, Rise and Fall of Theological Enlightenment, 86-88; Dinah Ribard, Raconter, vivre, penser histoires de philosophes, 1650-1766 (Paris: J. Vrin et Éditions de EHESs, 2003), 153, 271.

40 Wright, "Ruggiero Boscovich," 359-6o.

41 Wright, "Ruggiero Boscovich," 355-58. 
Orthodox Christianity. For, Boscovich also published a widely read and translated account of his travels through Ottoman Bulgaria and Moldavia (Eastern Romania today), and throughout the kingdom of Poland-Lithuania. ${ }^{42}$

As is now well attested by scholarship, a vital component of Jesuit contributions to the seventeenth and eighteenth centuries was their painstaking scientific research and teaching. Not only was natural science an important component of Jesuit missionary activities, but individual Jesuits like Boscovich and Francesco Grimaldi (1618-83), whose work influenced the development of Newton's optics, added significantly to the scientific revolution that accelerated throughout the seventeenth century and achieved popularization by the philosophes and others (including by the Jesuits themselves) during the high noon of Enlightenment in the eighteenth century. ${ }^{43}$

Yet, despite the importance many Jesuits ascribed to natural philosophy, Jesuits did not believe in the perfectibility of human society through natural revelation alone. Because the moral, religious, and scientific enlightenment of humankind was limited by the imperfections of sense perfection, Jesuits remained convinced that postlapsarian human reason was powerless to fully recover the original, pristine religion of God without special revelation through the sacred theology and mysteries of the Catholic faith. In this, Jesuit contributors to the Enlightenment depart rather starkly from the most radical naturalists of the Enlightenment who believed that mind was itself, matter, and remained capable of dynamism and perfectibility through reason even without divine providence. ${ }^{44}$ Natural science - just like philosophy, history, and textual erudition - brought illumination and improvement to human culture in part, and paradoxically, because it also pointed to the limitations of

42 Wright, "Ruggiero Boscovich," 358; on Boscovich's travel narrative and what Wright calls his "nuanced analysis of local Orthodox religion," see Larry Wolff, Inventing Eastern Europe: The Map of Civilization on the Mind of the Enlightenment (Stanford: Stanford University Press, 1994); Wolff, "Boscovich in the Balkans: A Jesuit Perspective on Orthodox Christianity in the Age of Enlightenment," in Jesuits, vol. 2: Cultures, Sciences, and the Arts, 738-57.

43 Wright, "Ruggiero Boscovich," 359-6o; Andrés Prieto, Missionary Scientists: Jesuit Science in Spanish South America, 1570-1810 (Nashville: Vanderbilt University Press, 2011); Louis Caruana, "The Jesuits and the Quiet Tide of the Scientific Revolution," in Cambridge Companion to the Jesuits, ed. Worcester, 243-6o; Victor Navarro Brotóns, "Science and Enlightenment in Eighteenth-Century Spain: The Contribution of the Jesuits before and after Expulsion," in Jesuits, vol. 2: Cultures, Sciences, and the Arts, 390-404.

44 For this definition of naturalism, see Kors, Epicureanism and Unbelief, 139-40; and Kors, Naturalism and Unbelief, 274; see also Burson, "Distinctive Contours of the Jesuit Enlightenment in France," 221. 
human knowledge and the need for Catholic revelation. As Mark A. Waddell has pointed out, early modern Jesuit science gradually evolved toward "the sober admission that, indeed, much of nature is mysterious and difficult to know, that our senses may trick or fail us, that ignorance and uncertainty are more common than we might wish," but withal, a via media (middle way) is to be found between "the pitfalls of dogmatism and sensual fallibility" if one abandons "pursuit of certainty" by means of reason alone..$^{45}$ The synthetic methods and "mitigated skepticism" associated with the Jesuits is symptomatic of still another important pattern associated with the emergence of eighteenthcentury culture: as Anton M. Matytsin has recently suggested, the skeptical crises of the seventeenth century stimulated early Enlightenment figures to focus on projects of reform and improvement based on practical, empirical reason that proceeds from a clarified understanding of the depths of its own limitations. ${ }^{46}$

\section{Jesuit Historical Apologetics and Historicism}

These characteristics of Jesuit natural philosophy also facilitated the development of Jesuit historical apologetics. ${ }^{47}$ Believing that Catholic revelation was a necessary bulwark against the postlapsarian corruption of perception and human reason, Jesuits helped pioneer a style of apologetics that combined the genre of universal history so prominent in the late seventeenth and eighteenth centuries (particularly, universal histories of philosophy and religion) with attempts to demonstrate the historical authenticity of the body of Catholic teachings. ${ }^{48}$ Accordingly, therefore, Jesuits like Claude Buffier became leading developers of critical methods of historical scholarship designed to show that

45 Mark A. Waddell, Jesuit Science and the End of Nature's Secrets (Burlington, VT: Ashgate Publishing, 2015), 189-90.

46 Matytsin, Specter of Skepticism, 268-74; for "mitigated skepticism," see Richard Popkin, History of Scepticism from Erasmus to Spinoza (Berkeley, CA: University of California Press, 1979), 129-50; also Anton M. Matytsin and Jeffrey D. Burson, Introduction to Skeptical Enlightenment: Doubt and Certainty in the Age of Reason, ed. Jeffrey D. Burson and Anton M. Matytsin (Oxford: Oxford University Studies on the Enlightenment, 2019), 1-20. On patterns of eighteenth-century apologetical theology, see Didier Masseau, Les ennemis des philosophes: L'Antiphilosophie au temps des Lumières (Paris: Albin Michel, 200o); Anton M. Matytsin, "Reason and Utility in French Religious Apologetics," in God in the Enlightenment, 63-82; and William R. Everdell, Christian Apologetics in France, 1730-1790: The Roots of Romantic Religion (Lewiston, NY: Edwin Mellen, 1987).

48 Burson, "Distinctive Contours of Jesuit Enlightenment in France," 223-25. 
even if sacraments and mysteries were not strictly speaking rational, the body of orthodox teaching and the authenticity of biblical texts rested on a historically sound basis dating to within living memory of Jesus Christ. ${ }^{49}$ Relatedly, this new style of Jesuit apologetics lent further impetus to the study of religious and philosophical texts compiled by missionaries, and those of the nearer ancients of Greece and Rome, in order to understand the origins of idolatry and the process by which the purportedly universal religion became corrupted. In short, Jesuits were among many pioneers in two related tendencies characteristic of Enlightenment Catholicism: first, a shift toward positive, apologetical theology geared toward an expanding lay readership, and second, the related tendency of making the science of theology dependent upon universal histories of philosophy and comparative religion. ${ }^{50}$

But, Jesuit historical scholarship, much like the work of Jesuit missionary scholarship, had implications that far transcended the apologetic interests of the Society itself. As Paul Shore's contribution argues, Adam František Kollár, despite having left the Jesuit order early in his career, went on to write important works on the historic rights of the Hungarian crown and on the history of the Ruthenian people. Kollár's historical works effectively coined the term "ethnology" (ethnologia) as "the science of nations and peoples" conducted by means of studying "the origins, customs, languages and institutions of various nations," as well as "their fatherlands and ancient seats."51 György Pray, another Jesuit studied by Shore, continued to publish on Hungarian history and antiquarianism after the papal suppression of the Society of Jesus with the breve, Dominus ac redemptor in 1773. Pray discovered the earliest text written

49 Burson, Rise and Fall of Theological Enlightenment, 64-70, 207-13; Northeast, Parisian Jesuits, 65; Ehrard, L'idée de la nature en France, 424-25.

5o On the commercialization of the public taste in apologetics and the transformation of "Christian Enlightenment," see Mark Curran, Atheism, Religion and the Enlightenment in Pre-Revolutionary Europe (Suffolk, UK: Boydell \& Brewer, 2012); on the development of modern historical sensibility and methods among seventeenth- and eighteenth-century writers, see Matytsin, Specter of Skepticism, 233-63; on the Jesuit role in the origins of modern conceptions of "religion" and religious studies, see Stroumsa, New Science, 1-13, $145^{-57}$.

51 Adam František Kollár, Historiae iurisque publici regni Hungariae amoenitates, 2 vols. (Vienna: Typis a Bavmeisterianis, 1783), 1:80: “[...] notitia gentium populorumque, sive est id doctorum hominum studium, quo in variarum gentium origines, idiomata, mores, atque instituta, quo in variarum gentium origines, idiomata, mores, atque instituta, ac denique patriam vetustasque sedes eo consilio inquirunt, ut de gentibus populisque sui aevi rectius judicium ferre possint." Qtd. Shore, "Ex-Jesuit Librarian-Scholars Adam František Kollár and György Pray: Baroque Tradition, National Identity, and the Enlightenment among the Jesuits in the Eastern Habsburg Lands," $447 \mathrm{n} 7$ of this issue. 
in Hungarian and published extensively on the history of the kingdom of Hungary and its peoples. Jesuit formation, as Shore argues, allowed Kollár and Pray to employ their skills in textual erudition to engage actively, and with originality, on questions of concern to the Enlightenment Republic of Letters even after the abandonment of their vocations and the papal suppression of the order, itself. Jesuit methods remain evident in the persistent interest of both scholars in authenticating historical accounts through the comparison and contrast of documentary evidence. Moreover, implications presaging Romantic nationalism emerge from Kollár's attempt to define human populations in accordance with the history of their language, literature, and historic territorial fatherlands. Finally, Pray's activities in promoting education often align with concerns of more secular scions of the Enlightenment in a society significantly transformed by the increasingly post-confessional milieu of the last third of the eighteenth century.

The debate over what, and among whom, was the Enlightenment actually turns on the question of historical agency: the issue of whether or not historians should refer to the "Enlightenment" as only that which emerged from individuals or institutions whose self-described reformist ends, and self-fashioned intellectual genealogies rhyme with the popular understanding of the Enlightenment today. But, if "Enlightenment" is understood as the multifaceted process of cultural transformation - a long cultural revolution of sorts-that characterized the culture of the European and Euro-Atlantic Republic of Letters as a whole throughout the 1600 -170os, then it immediately becomes evident that a variety of reformist ends were sought, and not just those most commonly studied as having belonged to the philosophes, or to the prophets of naturalism comprising what is commonly understood (in its most ecumenical sense) as the radical Enlightenment. ${ }^{52}$ If a process of revolutionary cultural change was underway across the expanding erudite publics of early modern Europe and its associated empires between the late Renaissance and the onset of the age of Revolution, one might just as readily and plausibly speak of this "enlightening culture" as the process created from dialog and clashes among forms of Enlightenment as common to the early philosophes as they were to

$5^{2}$ Jeffrey D. Burson, "Refracting the Century of Lights: Alternate Genealogies of Enlightenment in Eighteenth-Century Culture," in Let There Be Enlightenment, 227-46; on the notion of the Enlightenment as "cultural revolution," see Vincenzo Ferrone, The Enlightenment: History of an Idea (Princeton: Princeton University Press, 2015), vii-xvi, 155-72. 
many scholarly clerics and Catholic writers, including and perhaps especially, those who populated the summit of the Society of Jesus.

Still another reason for defining the various "Enlightenments" less in terms of their respective goals or the agency of their participants, and more in terms of how dialogs, debates, and arguments intersected and transformed the culture of the Republic of Letters from which they emerged, is that this latter perspective can more clearly illuminate the deeper origins of the Enlightenment overall. This more nuanced origins story exposes a more detailed tableau in which innovations derived from the self-consciously Catholic Reformist missionary and scholarly impulses of individual Jesuits-impulses often inherited from earlier humanism deployed in service of confessional polemicsironically contributed to the emergence of a more radicalized and secularized naturalism among eighteenth-century philosophers (even if one must acknowledge that many Enlightenment philosophes and radicals subverted the Jesuits' original purposes). ${ }^{53}$ When considered in this way, Jesuit preoccupations and proceedings of the sixteenth through eighteenth centuries (as, for example, their pervasive commitment to philosophy as the handmaiden of theology) might just as readily facilitate what Margaret C. Jacob has defined as the "creation of a new form of religiosity" in the eighteenth-century. ${ }^{54}$ Such was certainly the case with François de La Pillonnière, who began his career as a Jesuit by denouncing Malebranche and the Malebranchian proclivities of Yves Marie André (1675-1764), the Jesuit professor at College La Flèche. Ultimately, he found himself drawn so deeply into his study of Cartesianism that his zeal for philosophy impelled his abandonment, first, of the Society of Jesus, and finally, his commitment to Catholicism overall. La Pillonière's conversion to Protestantism, as Daniel J. Watkins has insightfully shown in a recent article, resulted paradoxically from his zealous approach to philosophical rationalism as a tool of piety and faith. Almost no Jesuit would have approved of where La Pillonière's pious philosophizing led him. But, impossible to deny from the vantage point of hindsight is the fact that the cultural and intellectual history

53 For further development of this interpretation of the Enlightenment, and on the Jesuits' place within it, see Burson, Culture of Enlightening; also Burson, "Distinctive Contours of Jesuit Enlightenment in France," 212-34; my current book project examines the Jesuit contribution to the Enlightenment within a an expanded periodization and in global and transcultural perspective: Burson, A Cultural History of the Jesuits in the Age of Enlightenment: A Global History (in progress).

54 Margaret C. Jacob, "Epilogue: Dichotomies Defied and Revolutionary Implications of Religion Implied," Historical Reflections/Réflexions historiques 40, no. 2 (2014): 108-15, here 110. 
of the Jesuit order contains within itself the ironic origins of an Enlightenment that was an age of renewed and redefined faith as well as of reason. ${ }^{55}$

Even so, Jesuit Enlightenment is not most usefully understood as characterizing the institution of the Society of Jesus as a whole. Regional institutional cultures and the agency of individuals exercised a profound influence on the shape of the Jesuit contributions to the long Enlightenment in ways that continue to warrant investigation. For example, the Mémoires de Trévoux, often liberally seasoned praise with opprobrium in its reviews of Pierre Bayle's work, especially when the latter wrote Réponse aux questions d'un provincial in rebuttal to Pascal. Tournemine, one of Trévoux's most celebrated long-time editors, was shockingly unconcerned by Bayle, thinking him to be little more than an ingenious rhetorician, while on the other hand, Jesuit professor of theology and philosophy in Strasbourg, Ignace de Laubrussel (1663-1730), excoriated Bayle's Dictionnaire philoosphique et critique as a montage of serious errors offered by a veritable prince of libertines. ${ }^{56}$ Laubrussel's evaluation presaged that of Jacques LeFebvre, the professor of philosophy at the Jesuit college of Douai, whose Bayle en pétit (1737) digested Bayle's Dictionnaire in the process of refuting it, and in so doing, served only to further disseminate Bayle's most suspect arguments (the work was liberally republished beginning the very next year). ${ }^{57}$

Similar internal tension explain a perplexing aspect of Jesuit history during the seventeenth and eighteenth centuries: namely that, despite a rhetorically vehement and enduring institutional commitment to official church teaching, to Aristotle, and to the neo-Scholastic approach of the Ratio studiorum, individual Jesuits, in a variety of different ways, slowly and tacitly loosened their bonds of commitment to Aristotle up to, but never formally beyond, the breaking point. ${ }^{58}$ Boscovich, the admirer and adaptor of Newton and innovative precursor of nineteenth- and twentieth-century physics, was nevertheless, at least nominally, a cautious Copernican at best. ${ }^{59}$ Claude Buffier (1661-1737), the cautious admirer and synthesizer of Cartesian and Lockean epistemologies (despite the Society's official censure of the former and wary, ephemeral,

55 Daniel J. Watkins, "The Two Conversions of François de La Pillonnière: A Case Study of Rationalism and Religion in the Early Enlightenment," Eighteenth-Century Thought 6 (2016): 33-59; for the notion of the Enlightenment as "an age of faith as well as reason," see Carl L. Becker, The Heavenly City of the Eighteenth-Century Philosophers, $2^{\text {nd }}$ edition (New Haven: Yale University Press, 2003), 8.

56 On diverse appreciation of Bayle among the Jesuits, I am indebted to the account in Matytsin, Specter of Skepticism, 74-75.

57 Matytsin, Specter of Skepticism, 86-87.

58 Wright, "Ruggiero Boscovich," 360-62.

59 Wright, "Ruggiero Boscovich," $362-63$. 
approach to the latter), nevertheless did so in order to update the Jesuit commitment to Aristotelian scholasticism. ${ }^{60}$ Neither the more innovative approaches of Boscovich nor Buffier were universally accepted by the Jesuit order: Boscovich had many critics among his fellow Jesuits, and Buffier's innovative flirtations with John Locke and Descartes seem to have gained far less purchase outside of France than did his linguistic and historical pursuits, as recently noted by Francisco Sánchez-Blanco. ${ }^{61}$ But, Jesuits such as Boscovich and Buffier are instructive for the nature of Jesuit Enlightenment in two ways. First, they were among the many public-facing Jesuit scholars who interacted lavishly with the academies, salons, and nascent public sphere afforded by the Enlightenment. Second, their work demonstrates the productive tensions that often prevailed between the bold and brilliant innovations of individual Jesuits, and the Society's long-standing institutional commitments to the polymathic ideal of humanistic erudition, and to the neo-Scholastic ideal of synthesizing new ideas and methods with orthodox Catholic theology and tradition. ${ }^{62}$ As Ulrich Lehner has helpfully summarized, often, "Jesuits described their explorations and achievements in modern science as an organic development of ancient thought," and this alien rhetoric often masks their more innovative approaches, sources, and conclusions. ${ }^{63}$

Daniel J. Watkins's contribution to this volume focuses on just one such productive tension within the order, and argues that inter-institutional dialog, debate, and tensions remain a vital and still much neglected facet of the cultural and intellectual history of the Jesuits during the Enlightenment. By focusing on the idiosyncratic and controversial French Jesuit Jean Hardouin (1646-1729), as well as the controversies within the Jesuit Order ignited by Hardouin's work,

6o Jeffrey D. Burson, "Claude G. Buffier and the Maturation of the Jesuit Synthesis in an Age of Enlightenment," Intellectual History Review 21, no. 4 (2011): 449-72.

61 Francisco Sánchez-Blanco, “La filosofía del 'sentido común' y el programa pedagógico de Claude Buffier," CES 18, no. 26 (2016): 357-82.

62 For Wright's scholarly network, see Wright, "Ruggiero Boscovich," in Exploring Jesuit Distinctiveness, $355^{-63}$, and note especially $360-62$ for what Wright calls the "simmering tension between Jesuit hierarchy and more adventurous individual Jesuits," to which my analysis above is here indebted; for more on Buffier's intellectual networks and impact on the French Enlightenment, see Katharine J. Hammerton, "A Feminist Voice in the Enlightenment Salon: Madame de Lambert on Taste, Sensibility, and the Feminine Mind," Modern Intellectual History 7 , no. 2 (2010): 202-38; and Hammerton, "Malebranche, Taste, and Sensibility: The Origins of Sensitive Taste and a Reconsideration of Cartesianism's Feminist Potential," Journal of the History of Ideas 69, no. 4 (2008): 533-58; Kathleen Wilkes, A Study of the Works of Claude Buffier (Geneva: Institut et Musée de Voltaire Les Délices, 1969; and Burson, Rise and Fall of Theological Enlightenment, $33^{8}-54$. Lehner, Catholic Enlightenment, 106. 
Watkins particularly shows how Hardouin's historical criticism-a response to the late seventeenth- and early eighteenth-century crisis of skepticism over the possibility of reliable historical knowledge-effectively compelled other Jesuit scholars to craft new epistemological arguments. In this way, Watkins suggests that, far from being marginal to the intellectual history of the Jesuits in France, Hardouin's work sparked definitive controversies among the Jesuits themselves - controversies that helped to further advance French Jesuit engagement with Enlightenment discourse and sensibilities.

Finally, as the work of Yasmin Haskell has recently suggested, if there was a Jesuit Enlightenment, it should also be sought beyond the vernacular literature and apologetics through which the Jesuits communicated to an expanding audience of eighteenth-century readers and an increasingly hungry market for printed books. In didactic verse, in letters, and in lengthy, often superficially hide-bound and obscure works still written in Latin, Jesuits communicated their inmost thoughts, speculations, and emotions. ${ }^{64}$ In short, Jesuit erudite culture also underwent its own kind of slow but significant rhetorical revolution from the sixteenth-century foundation of the Jesuit order until Dominus ac redemptor (1773) and beyond. Although still conducted in Latin as much as (or more than) in the vernacular, this early modern rhetorical transformation should not be neglected or underestimated. Often a product of their expanding global engagement through missions, and informed by zeal for the sacred and secular potential of natural philosophy, this history of Jesuit correspondence, verse, philosophy, science, and theological debate - whether penned in Latin or in the European vernaculars-entangled with and shaped broader currents of the early Enlightenment, engaging the mind, heart, and soul in significant ways that lasted well into the nineteenth century and beyond.

\section{Acknowledgement}

I wish to thank, both the anonymous reviewers of this introduction, and my friend and colleague, Daniel J. Watkins, for reading and carefully commenting on earlier drafts of this work. Whatever merits this contribution may possess have been significantly augmented by the gracious assistance of the aforementioned; any deficiencies or remaining lacunae herein are, of course, solely the responsibility of the author.

64 Yasmin Haskell, Loyola's Bees: Ideology and Industry in Jesuit Latin Didactic Poetry (Oxford: Oxford University Press, 2003). 